\title{
Computer-Based Software for Grammar Test: What Students Think about It?
}

\author{
Widyani Solihat, Ngadiso, Slamet Supriyadi \\ English Department, Universitas Sebelas Maret, Surakarta, Indonesia \\ Email: solihat.widyani@gmail.com
}

How to cite this paper: Solihat, W., Ngadiso, N., \& Supriyadi, S. (2018). Computer-Based Software for Grammar Test: What The Students Think about It?. International Journal of Language Teaching and Education, 2(3), 303-314.

https://doi.org/10.22437/ijolte.v2i3.5754

Accepted: October 18, 2018

Published: November 30, 2018

Copyright (c) International Journal of Language Teaching and Education. This work is licensed under the Creative Commons Attribution International License (CC BY 4.0).

http://creativecommons.org/licenses/by/4 $0 /$

(c) (i)

\begin{abstract}
A test is conducted to know the students' competencies toward the material that they have been learned. Making the test is not easy because the lecturers have to consider the material or skill which will be tested, in this case is grammar. The lecturers also must use the test media which is appropriate and interesting. Nowadays, the utilizing of technology in education context has increased, especially in conducting the test. The aim of this research is to show the students' perception toward computer-based software for grammar test. This research used mixed method with descriptive analysis design. It was used individual interview technique and distributed questionnaire. For the interview, it was used qualitative data. For the questionnaire, it was used quantitative data. Thus, the qualitative and quantitative data were supported each other. The participants were from 40 English department students in one of university in Serang. The data were collected from questionnaire and interview with some students. The result shows that almost all students give positive response and perception toward computer-based software for grammar test. The students become more interesting to do the grammar test with the computer-based software and they are facilitated in conducting the test because they get benefits from it.
\end{abstract}

\section{Subject Areas}

Language Teaching

Keywords

Computer-Based Software, Grammar Test, Perception

\section{Introduction}

Grammar is one of the important aspects which have to be learned by the students while learning English in Indonesia. Every student in each level learns grammar in order to master English structure. Lock (1995) stated that grammar is a set of rules which include the grammatical structures of language and they are two aspects which 
have to be considered; the internal structure of the word and the arrangement of words. Thus, grammar is the core of English because it is the structures of language. The indicators of grammar which must be considered when reading, writing, speaking, and listening are the meaning, the rule, the form, and the pattern. Those indicators should be delivered well by the teachers because it will make the students master English well.

Learning grammar is a must when students are expected to acquire a language (Saraswati, 2015). Grammar becomes one of the crucial subjects which must be mastered in learning English because grammar is a core of English and its structure. Grammar is a dominant subject in school and university in English department because there are four semesters of learning grammar. It shows that grammar is important to be learned by the students but they always assume it as one of the difficult subjects because of the differences between Indonesian and English grammar. In reality, teaching English grammar is basically just the same as any other subjects. The problems might come from the lack of motivation of the students and teaching process delivered by the lecturer while teaching grammar. The other cause of this problem might come from the absence of media to fulfill the teaching and learning needs of the lecturer and the learners especially in grammar subject.

Grammar test is important to be conducted in order to know the students' achievement in grammar ability. Testing of grammar is one of the major components of language testing. The ability in mastering the language can be seen in how the students master the grammar ability because it is the basic knowledge of language. Madsen (1983) said that grammar test is designed to measure students' proficiency. Grammar is related to syntax and it involves the relationship of words in a sentence, such as word order, the using of connectives, negative and question forms. Madsen also stated that there are two basic ways in measuring grammar ability; individual testing and group testing. Individual testing is the best way to know every student's achievement in grammar ability individually. Besides, group testing is the best way to make the students more unified and do the test collaboratively.

Moreover, there are some basic types of tests which are usually used by the teacher in testing grammar to measure the students' achievement in grammar ability. Heaton (1988) stated that there are some types of tests which are mostly used to test the students' grammar achievement. The types of tests are multiple choice, error correction, completion items, transformation items, items involving the changing of words, 'broken sentence item', pairing and matching items, and combination and addition items. The teacher usually uses multiple choice tests because it is easier to be corrected and score. Moreover the students also like to do the test in multiple choice types.

Nowadays, schools are integrating all sorts of new technologies in their classes, such as computers, tablets, interactive whiteboards or even mobile phones (Pardo, 2014). Utilizing technologies in education area has increased because of the 
globalization process. Most of universities in Indonesia have supplied LCD projector in every class and language laboratory to support the learning process. Both students and teacher have different needs in utilizing the technology in the classroom. The students can enhance their ability in using technology and the lecturer can be assisted with technology in teaching and learning process. Moreover, facilitating technology in the classroom makes the learning process easier. The learners who receive computer-based lessons outperform those who use paper-based materials (Pardo, 2014).

Luecht and Sireci (2011) stated that computer-based test has been significantly grown over the past four decades as an alternative way to paper and pencil test. However, the implementation of CBT is neither easy nor inexpensive. Computer-based testing (CBT) has emerged as one of most pursued by states in the recent "innovative" way of assessments. CBT can be very useful because it is having speedier and cheaper test delivery for state and district-wide assessments. It is also seen by some as an avenue toward greater accessibility for students with disabilities. Thurlow et al. (2010) explore the context of CBT, current state computer-based tests, and considerations for students with disabilities, in part as follow-up to a similar exploration that occurred in the early 2000s when just a few states were beginning to develop and implement CBT for their state assessments. Nine considerations for states and districts are presented: (1) Consider the various beliefs and assumptions of stakeholders toward CBT; (2) Consider the whole system; (3) Consider the students' need; (4) Consider for bringing the expert of computer; (5) Consider for making the policies in utilizing CBT; (6) Consider the tracking of using CBT accessibility features; (7) Consider the CBT has been feasible to be used; (8) Consider the students who have disabilities; (9) Consider for training the students and teachers about CBT. CBT also gives many advantages for teachers and students. The teachers can take up less effort and time, can save all data in the computer, can monitor the students while doing the test, and can minimize human errors in scoring and grading. The students can get score and feedback directly, can do the test wherever if the test is internet-based, and can minimize their bad habit on cheating.

Pardo (2014) reported his study about analyzing the education of students' acquisition in the secondary level of English grammar by using two different methods (computer-based instruction and paper-based instruction). This study aimed to explore and compare the effectiveness of these two methods and students' opinions on using paper-based materials and online materials. The result of questionnaires showed that using online materials makes the students more motivated than paperbased materials. The results also opened new paths of research about the using of ICTs for academic purposes.

The researchers investigate the use of computer-assisted English grammar test which is similar to those previous study. The researchers found that the use of media is effective in teaching and learning process and can improve students' grammar achievement. The previous study is about implementing computer and internet based 
in language learning in the school but the researchers of this research will try to find in the university level. The researchers believe that it will be more effective to use computer-assisted English grammar test software as a media in grammar test process because the students in the university level understand computer and technology. The grammar test software is made by the researchers and it is a new media for grammar test which can be implemented in the classroom. Besides, the researchers try to find and show the students' perception toward computer-based software for grammar test.

\section{Method}

This research used mixed method with descriptive analysis design. It was used individual interview technique and distributed questionnaire. For the interview, it was used qualitative data. For the questionnaire, it was used quantitative data. Thus, the qualitative and quantitative data were supported each other. The formula for quantitative is as follows:

$$
\mathrm{P}=X i / X \times 100 \%
$$

Explanation:

$\mathrm{P} \quad=$ Assessment percentage

$X i=$ Score obtained

$X$ = Maximum score

The researchers used purposive sampling for conducting the research. Participants of this research are 40 English department students of Sultan Ageng Tirtayasa University. This research was conducted in the language laboratory of Sultan Ageng Tirtayasa University. The questionnaire was distributed to all participants and the interview was conducted to the six English department students who have different ability (high, medium, and low). The interview was done to gain more information about students' perception toward computer-based software for grammar test. In the beginning, the researchers introduced how to use CBT to the students and gave the instructions. Then, the students were asked to do the grammar test on the computer software. After finished the test, the students were distributed the questionnaire to be filled to know their responses toward computer-based software for grammar test. At last, the researchers interviewed some students and distributed questionnaire to gain their perceptions toward the grammar test which used computer software. The researchers analyzed the data from questionnaire and interview, and then she concluded it.

\section{Findings and Discussion}




\subsection{Findings}

The findings of this research show the students' perception toward computerbased software for grammar test. The grammar test was made by the lecturer and the sources adopt from TOEFL book. The grammar test was also made based on the lesson plan of a semester (RPS) from the lecturer. The grammar test was conducted to achieve the students' learning objectives. The materials of the grammar test can be described below on the table:

Table 3.1.1 Description of the lesson plan for a semester

\begin{tabular}{|c|c|}
\hline Materials & Learning Objectives \\
\hline Noun phrase structure & $\begin{array}{l}\text { Students can make sentences using noun } \\
\text { phrase in simple present form. }\end{array}$ \\
\hline Verb phrase structure & $\begin{array}{l}\text { Students can make sentences using verb } \\
\text { phrase structure. }\end{array}$ \\
\hline Adjective phrase structure & $\begin{array}{l}\text { Students can make sentences using adjective } \\
\text { phrase structure. }\end{array}$ \\
\hline Past continuous tense & Students can make past continuous sentences. \\
\hline Adverb phrase structure & $\begin{array}{c}\text { Students can make sentences using adverb } \\
\text { phrase structure. }\end{array}$ \\
\hline Prepositional phrase structure & $\begin{array}{l}\text { Students can make sentences using } \\
\text { prepositional phrase structure. }\end{array}$ \\
\hline Past future tense & $\begin{array}{l}\text { Students can make past future tense } \\
\text { sentences. }\end{array}$ \\
\hline Present perfect continuous tense & $\begin{array}{l}\text { Students can make present perfect continuous } \\
\text { sentences. }\end{array}$ \\
\hline Passive voice & Students can make passive voice sentences. \\
\hline Present perfect tense & Students can make present perfect sentences. \\
\hline Declarative & Students can make sentence types sentences. \\
\hline Exclamative or exclamation & $\begin{array}{l}\text { Students can make sentences using } \\
\text { exclamative. }\end{array}$ \\
\hline Interrogative for questions & $\begin{array}{l}\text { Students can make sentences using } \\
\text { interrogative. }\end{array}$ \\
\hline
\end{tabular}

From the description of the lesson plan for a semester, the students must able to make sentences using noun, verb, adjective, adverb, and prepositional phrases. The students must comprehend past continuous tense, past future tense, present perfect continuous tense, present perfect tense, and also passive voice. The students also must able to make declarative, exclamative, interrogative sentences. The examples of questions of each material are presented below:

The students give positive response toward computer-based software for grammar test. The students feel more interesting to do the grammar test with computer-based software. CBT can help them in conducting the grammar test. The students can also operate the computer-based software for grammar test easily. It can be seen from the results of the questionnaire.

Table 3.1.2 Students' response toward computer-based software for grammar test 


\begin{tabular}{|c|c|c|}
\hline Statement & $\mathrm{f}$ & $\%$ \\
\hline Instruction of the test is clear. & 39 & 97 \\
\hline Quality of the questions is good. & 39 & 97 \\
\hline $\begin{array}{l}\text { Questions of the test are suitable with the materials which } \\
\text { have been learned. }\end{array}$ & 40 & 100 \\
\hline Questions of the test are suitable with learning objectives. & 40 & 100 \\
\hline Kind of font is good and can be read. & 39 & 97 \\
\hline Size of font is good and can be read. & 39 & 97 \\
\hline Software coloring background is good. & 39 & 97 \\
\hline Icon menu design is interesting. & 40 & 100 \\
\hline Account security is good. & 40 & 100 \\
\hline Account setting can be operated easily. & 40 & 100 \\
\hline $\begin{array}{l}\text { There is time countdown automatically when beginning the } \\
\text { test. }\end{array}$ & 40 & 100 \\
\hline There is music player when doing the test. & 40 & 100 \\
\hline The software can save the test result automatically. & 40 & 100 \\
\hline The software can show the feedback or note from the lecturer. & 40 & 100 \\
\hline The software is useful for accessing the saving test result. & 40 & 100 \\
\hline $\begin{array}{l}\text { The software is useful for facilitating the students in } \\
\text { conducting test. }\end{array}$ & 40 & 100 \\
\hline The software is useful for showing the test score directly. & 40 & 100 \\
\hline $\begin{array}{l}\text { The software is useful for reviewing the test result, so the } \\
\text { students can identify their weaknesses and difficulties in } \\
\text { grammar. }\end{array}$ & 40 & 100 \\
\hline The software is useful for printing the test result. & 40 & 100 \\
\hline
\end{tabular}

From the result of the questionnaire, it can be seen that all items regarding the computer-based software for grammar test got $97 \%$ - 100\%. It can be concluded that mostly students agree with the statements. There is only one student who stated "no" toward the statements in the questionnaire. A student who stated "no" toward the statements in the questionnaire did not fill the the statements: (1) The instruction of the test is clear. It may happen because he or she did not understand well about the instruction of the test. (2) Quality of the questions is good. It may happen because he or she feels that the quality of the questions is not good enough. (3) Kind of font is good and can be read. It may happen because he or she cannot read it well and he or she feels that the kind of font is not interesting. (4) Size of font is good and can be read. It may happen because he or she feels that the size of font is small so he or she cannot read it well. (5) Software coloring background is good. It may happen because he or she feels that the color of software background is not good so he or she is not comfortable to see the screen.

From this result furthermore, it can be said that computer-based software for grammar test is interesting and very useful for the students. The students also can know their score and test result directly after they finished the test. They can listen to the music during the test, so they can feel more enjoyable. They can manage their time in doing the test because there is time countdown on the software. They 
can see their saving test result to know their grammar ability and get the feedback or note from the lecturer. So, if they have weakness in grammar ability, they can overcome it sooner. The questions of the test are also suitable with the students who have learned all materials on the test, so the students can achieve their learning objectives.

Moreover, the result of the questionnaire itself should be supported by the result of the interview to make the data stronger and easier to conclude the students' response toward the computer-based software for grammar test. The detail of interview with six students who have different grammar ability (high, medium, and low) can be seen as follow:

Researcher : What do you think about the computer-based software for grammar test?

Student A : It is great and impressive miss.

Student B : The design is interesting and good-looking

Student C : I can see my score and test results directly. I become more understand where my weakness in grammar by reviewing and identifying my test result.

Student D : There is also right key answer directly if I answer the wrong question.

Student E : It is more interesting with the audio player in the software, so we can listen to the music while doing the test. It makes me more enjoyable during the test.

Student F : I can also get feedback or note from my lecturer for better improvement in grammar. The important thing is the computer-based software for grammar test is very interesting and very useful for us.

Researcher : Thank you all for your positive response. Then, are there any difficulties or weaknesses while doing the grammar test using the computer-based software?

All Students : No miss.

Student A : We can operate it easily and it facilitates us in doing grammar test.

Student D : We can get many advantages while doing grammar test which is used computer-based software, like the statements in the questionnaire.

Researcher : How about the questions of the test?

Student E : The questions are suitable for us because we have learned all materials regarding the questions.

Student F : It is good questions of the test because it tested us to think harder and read it carefully.

Researcher : Ok good. Is there any comment or suggestion?

Student C : No miss. It is great, interesting, and make us attracted to do the grammar test because it is using computer in this technological era. 
From the interview, it can be seen that the students also give positive response toward computer-based software for grammar test. The students said the similar answer with the questionnaire. Thus, it can be concluded from the questionnaire and interview data that almost all students give positive response toward computer-based grammar test software.

The pictures below are the screenshot of grammar test computer-based software:

Picture 3.1.1 Main Menu

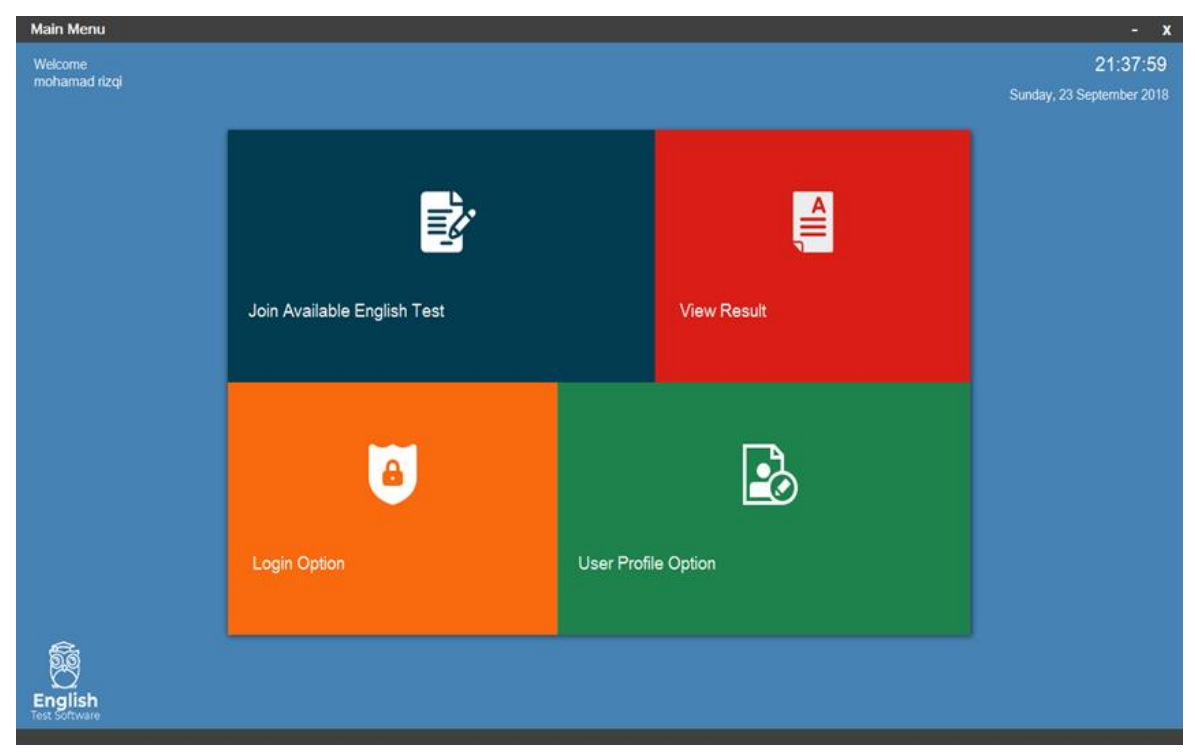

In the main menu, there are some menu which can be chosen by the students. The join available English test menu is used for joining the test that will be done by the students. The view result menu is used for seeing all students' test result that have been done and they can also review it to know their grammar ability. The login option menu is used for change the old password becomes new password. The user profile option is used for change the students' identity if there is something wrong.

Picture 3.1.2 Students' Test Sheet

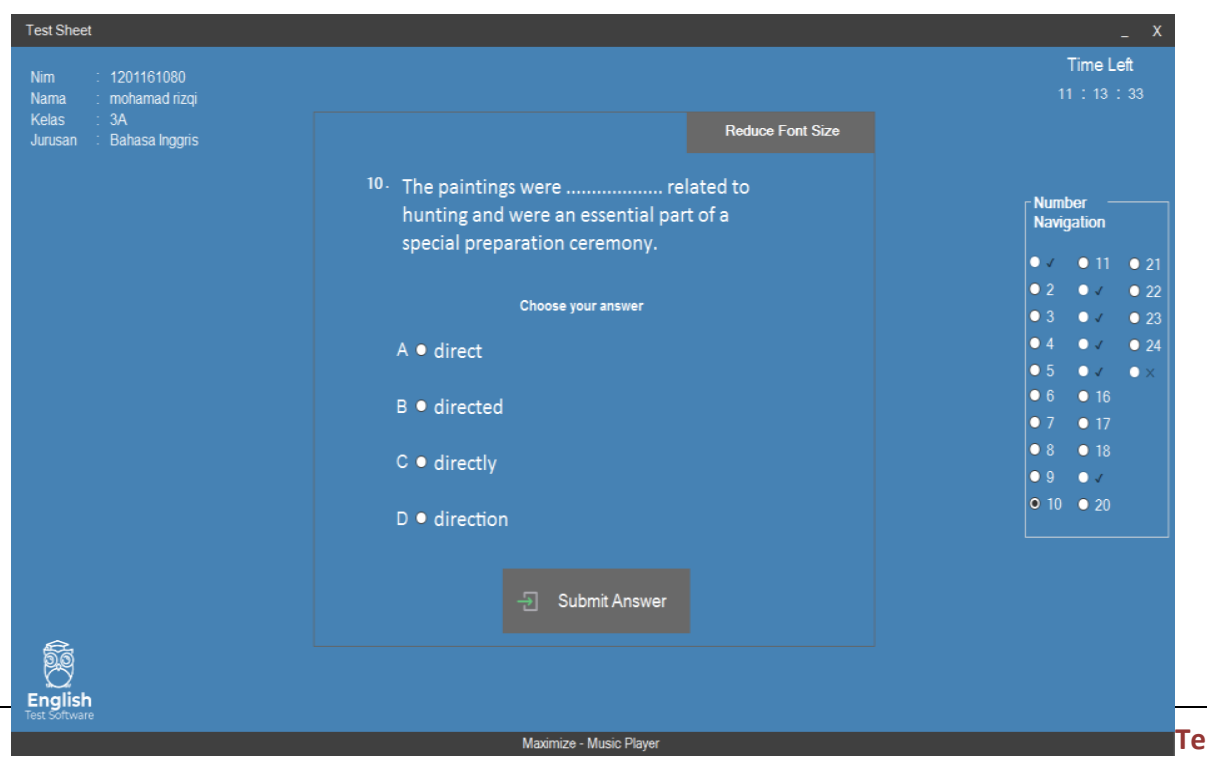


In the students' test sheet, there are students' identity which involve student's number, name, class, and program study. The questions and answer choice are placed in the middle. To choose the numbers of questions, there is at right side. There is also time countdown at the top right side. Besides, the students can increase and reduce the font size.

Picture 3.1.3 Students' Correct Answer

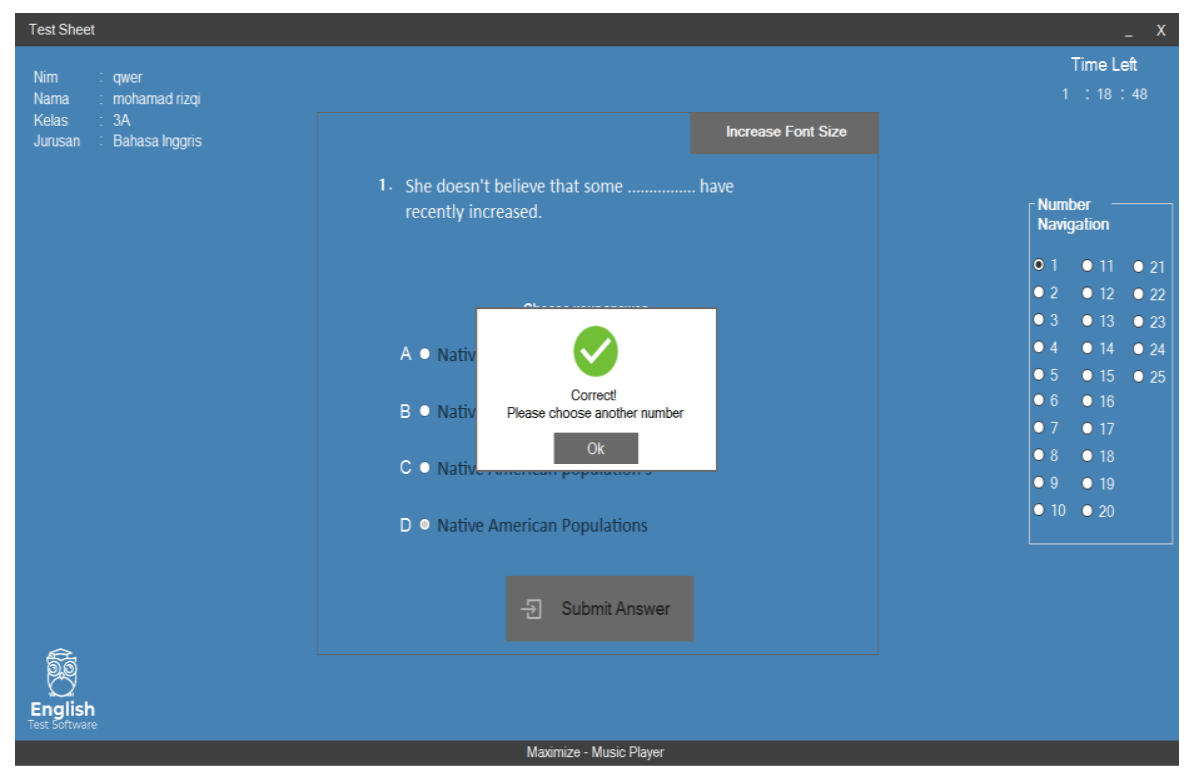

There will be checklist sign if the students choose the correct answer.

Picture 3.1.4 Students' Wrong Answer

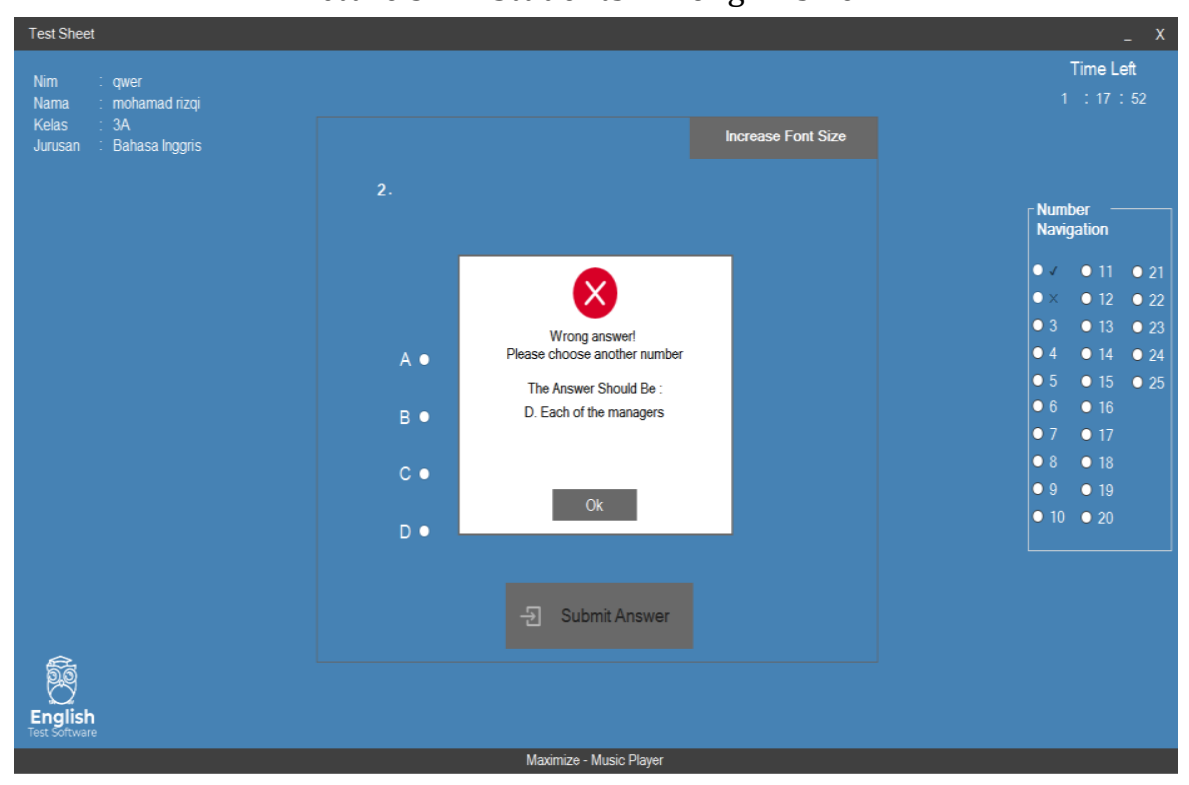

There will be cross sign if the students choose the wrong answer and there will be the right answer of the question that should be chosen by the students. 
Picture 3.1.5 Students' Test Result

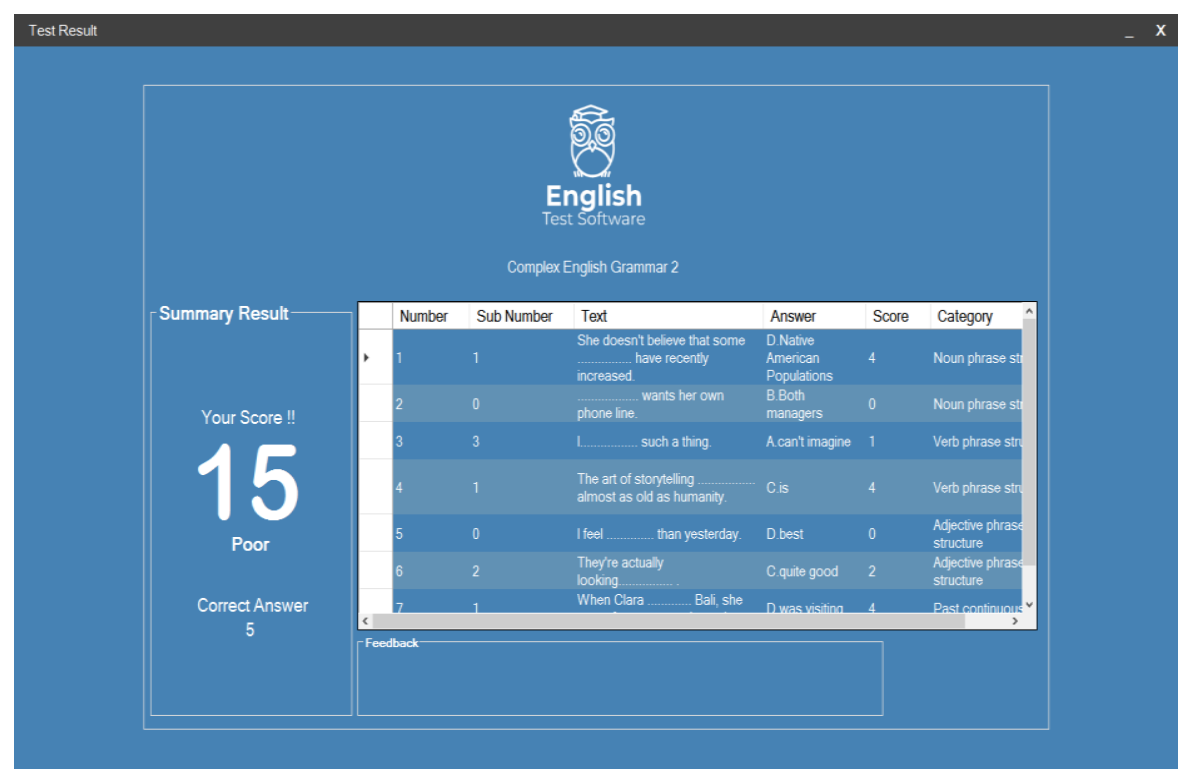

The score and test result will be showed directly after the test has finished. The students can see where is their weakness or mistake in grammar ability. The score in the picture is only the example and it is not the real students' result.

From the findings, it can be seen that almost all students respond positive toward computer-based for grammar test. Grammar is important for students in comprehending English. Learning grammar is a must when students are expected to acquire a language (Saraswati, 2015). The students must know their achievement in grammar ability by doing the test. Madsen (1983) said that grammar test is designed to measure students' proficiency. The questions of the test must suitable with the materials which have been learned the students before and represent the learning objectives. The questions of the test and the instructions also must have good quality. Lock (1995) stated that grammar is a set of rules which include the grammatical structures of language and they are two aspects which have to be considered; the internal structure of the word and the arrangement of words.

Heaton (1988) stated that there are some types of tests which are mostly used to test the students' grammar achievement. The types of tests are multiple choice, error correction, completion items, transformation items, items involving the changing of words, 'broken sentence item', pairing and matching items, and combination and addition items. In this research, the type of the test is multiple choice. It is easy to measure the score of the test if the type of the test is multiple choice. This type of the test is easier to be input to the computer software than the other types of test. Nowadays, schools are integrating all sorts of new technologies in their classes, such as computers, tablets, interactive whiteboards or even mobile phones (Pardo, 2014). Using the computer-based software for grammar test is the best way to be implemented in the classroom because the students and lecturer can connect each 
other and they are not left behind in this technological era. Moreover it can facilitate students in conducting the grammaar test.

The students feel more interesting to do the grammar test with computer-based software because the software coloring background is good, the icon menu design is interesting, and size and kind of font can be read. The students' account security is also good, so they can save their test result safely. Moreover the software is easily to be operated. Besides, the students get many benefits while doing the grammar test with computer-based software. They can know their test result and score directly, they can save their test result on the software, they can get feedbcak or note from the lecturer directly, they can print out their test result if they need it, and they can review the test result so the students can identify their weaknesses and difficulties in grammar. The learners who receive computer-based lessons outperform those who use paper-based materials (Pardo, 2014).

\section{Conclusion}

The conclusion which can be described of this research is the students' perception toward the computer-based software for grammar test. Almost all students give positive response toward the computer-based software for grammar test. The students feel more interesting to do the grammar test because it is using the computerbased software. It brings a new experience for students during the grammar test process because it may motivate the students to do the test and make them enthusiastic in following the test. The students also get some benefits by using the grammar test software. First, the students can do more practice about grammar because there are three questions in each number. Second, the students can know their grammar ability by identifying their test results, so they can overcome their weaknesses later. Third, the students can organize their time while doing the test because there is time countdown in the software. Fourth, the students can turn on or off music player in the software, so they can feel enjoy during the test. Fifth, the students can know their score directly. Sixth, the students can know the feedback from the lecturer after the test. Seventh, the students can save their test result and open it again if they need it. Eighth, the students can print out their test results. Thus, utilizing computer-based software for grammar test can get positive responses and perceptions from the students.

\section{References}

[1] Heaton, J. B. (1988). Writing English Language Test. New York: Longman Group.

[2] Lock, Graham. (1995). Functional English Grammar: An Introduction for Second Language Teachers (Cambridge Language Education). Cambridge Language Education: Cambridge University Press.

[3] Luecht, R. M., \& Sireci, S. G. (2011). A Review of Models for Computer-Based Testing. CA: College Board.

[4] Madsen, H. S. (1983). Techniques in Testing. New York: Oxford University Press. 
[5] Pardo, A. M. (2014). Computer-Based vs. Textbook-Based Grammar Instruction: Effectiveness and Students' Perceptions. Thesis. Máster Universitario en Formación del Profesorado de Educación Secundaria (UPNA).

[6] Saraswati, Dyah. (2015). The Use of Board Game to Improve Students' Grammar Mastery. Thesis. IAIN Salatiga.

[7] Thurlow, M., Lazarus, S. S., Albus, D., \& Hodgson, J. (2010). Computer-based testing: Practices and considerations (Synthesis Report 78). Minneapolis, MN: University of Minnesota, National Center on Educational Outcomes. 